\title{
Youth Migration as a Destabilizing Factor in the Spatial Development of Regions
}

\author{
Svetlana Arkhipova \\ Department of Economics and Finance \\ of the Humanitarian and pedagogical Academy (branch) \\ V. I. Vernadsky Crimean Federal University \\ Yalta, Russia \\ stavrsveta@rumbler.ru \\ Fernando Luis Munoz Andrade \\ Recruitment company Russian University \\ Quito, Ecuador \\ asesotia@russian-university.com
}

\author{
Natalia Rybalko \\ Department of Economics and Finance \\ of the Humanitarian and pedagogical Academy (branch) \\ V. I. Vernadsky Crimean Federal University \\ Yalta, Russia \\ natr19@mail.ru \\ Elena Piskun \\ Department of Finance and Credit, \\ Sevastopol State University \\ Sevastopol, Russia \\ lenapiskun@mail.ru
}

\begin{abstract}
The article analyzes migration processes in Russia in general and in Crimea, in particular. A predictive analysis of the Russian population age composition until 2035 has been carried out. It was shown on the theoretical works on the analysis of the migration impact on the spatial countries and regions development that this is a systemic problem, within which very little attention is paid to the problem of youth migration. This determined the purpose of the study. The purpose of the study is to analyze the impact of internal youth migration on the economic development of donor regions. Humanity is moving to a new technological order - the "knowledge economy", the basis of which is human intelligence. In such conditions, a person's knowledge becomes strategic resource of his country. $85 \%$ of economic growth in developed countries are based on knowledge as the main resource. This resource determines the quality of human capital. The problem of youth migration is considered both from the point of view of demography and from the point of view of the region's economy. The negative impact of migration processes on the socioeconomic and demographic state of donor regions in the future is shown. State measures to support youth in Russia are considered, problems, that are not addressed by state programs, are identified. The results of the study formulated the conclusions, which can be used in the measures development within development programs for the Crimean and other regions of the Russian Federation.
\end{abstract}

Keywords-human capital, youth migration, region, demography, economic development, Crimea.

\section{INTRODUCTION}

The integration of the economies of different countries inevitably leads to the acceleration of globalization. This is due to the development of technology, transport, means of communication and other achievements of mankind. This reasons create a new human environment, for example borders become open for each other, people become mobile and free in making choice not only for a field of activity, but also for a place of residence.

The struggle for tangible and intangible resources is the consequence of globalization. The main attention was paid to the «struggle» for natural and financial resources («physical capital») in the past centuries, then in the last decades information and labor resources, i.e. «human capital», are at the forefront. It was noted in the work [17]: «the structure of capital has undergone dramatic changes over the past two centuries. It was noted that over the past two centuries the capital structure has undergone dramatic changes. If in 1800 the basis of production was "physical capital", which accounted for $78 \%$, then already in 2000 its share decreased to $31 \%$, and "human" capital had taken $69 \%$ of total capital.

«Human capital» is a category consisting of professional knowledge and potential of a person (employee) or work collective, aimed at obtaining super-profits and ensuring the reproduction process» [17]. According to statistics, «85\% of economic growth in developed countries are based on knowledge as the main resource» [17]. This resource determines the quality of human capital.

The growing trend of the regional socio-economic development dependence on the quality of the «minds» working in these regions is observed. Employees who can easily adjust to new achievements and innovations become the most demanded given the pace of technological development. A young population with a «flexible mind», highly adaptive to new conditions, meets these criteria. That is why the chosen topic is relevant, since it is related to youth migration.

\section{METHODS}

General scientific methods of analysis and synthesis were used as research tools, as well as: calculation-graphic, economic-statistical, comparative financial-economic analysis, etc. 


\section{MAIN PART}

The problem of studying the man's place in the economy is not new. It was studied by such classic scientists as A. Smith, K. Marx GS, then G. Becker, M. J Taylor, S. Fisher, D. E. Bloom, J. G. Williamson understanding of the need «to invest the development of human capital to stimulate economic growth» was the result of their research $[1,2,7]$. People are always looking for more comfortable living conditions. Modern scientists [5,17,21] set new emphases in the studying of this problem. First of all, attention is drawn to the study of the relationship between the migration flow and the rates of region's development. An analysis of the attitude of every year $15 \%$ of graduates of Russian universities leave Russia [19]. From the «brain» drain Russia loses 50 billion dollars annually» [11]. At the same time, the share of Russia in the world market of high technology products is only $0.5 \%$ (for comparison, in Germany, 17\%) [11]. It is obvious that all these trends have a negative impact on the country's economic space.

This situation should be viewed «as an internal threat to Russia's economic security». Because «internal migration changes the size and composition of the population of different regions of the country, changing the situation on regional labor markets, the demographic burden on the

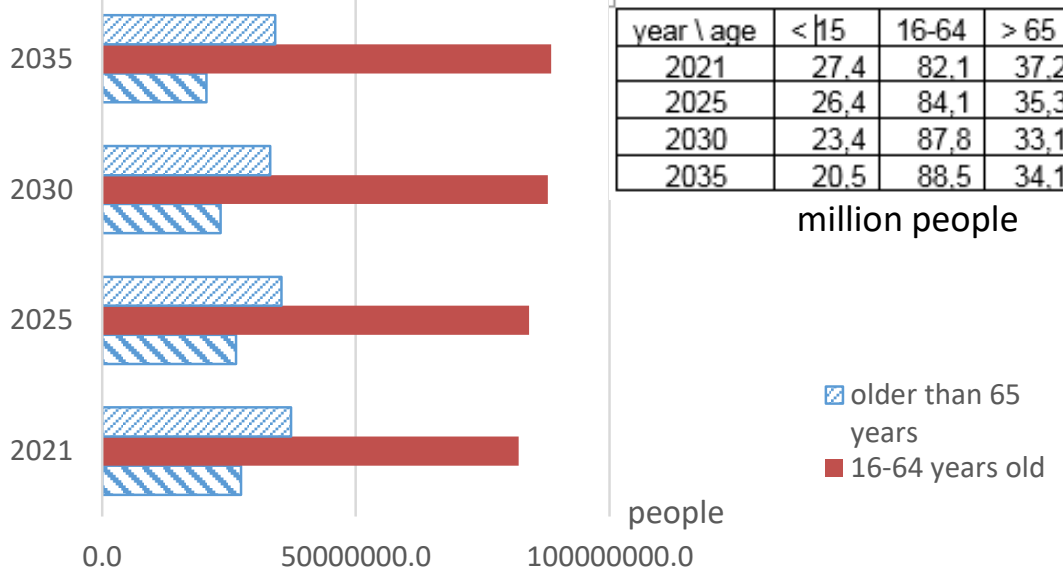

Fig. 1 Forecast of the structure of the population of Russia by age composition

Compiled by the author based on Rosstat [26]

scientists to this issue was carried out in the work of de Haas «Migration and Development ... »: «like a pendulum, from the optimism of supporters of development in the 1950s1960 s to the pessimism of the 1970s-1980s, and again towards more optimistic views in the 1990s and 2000s » [3]. Optimism and pessimism are considered from the point of view of the consequences of migration in this context, i.e. its repercussion for the economic development of regions.

«Migration optimists» consider migration as «a form of optimal distribution of factors of production in the interests of both sending and receiving» regions» [7]. Migration will contribute to «an evolution towards uncontrolled depletion of their already meager stocks of skilled labor - and the healthiest, most dynamic and productive members of their population» in sending countries according to «migration pessimists» [6]. De Haas points to the heterogeneity of the consequences of migration and the colossal «role of states in creating favorable conditions for the positive impact of migration on the development of regions» [3].

Such disputes do not subside even now. This is why studies of migration processes remain relevant. Youth migration is of particular concern. Young people make up a significant proportion of migrants worldwide: «28 million people between the ages of 15 and 24, accounting for 12 percent of the world's total migrants». [4].

There is also a problem of youth migration in Russia, which is of a centripetal nature and «flushes» young people out of the regions. This is extremely dangerous in the context of a demographic crisis for regional development. In addition, employed population and on the infrastructure of the region» [15].

The main part of scientific research in this area is devoted to assessing the influence of economic and social factors on the intensity of migration flows. On the other hand, the links between interregional population migration and the rate of economic development of the country and its regions remain largely unexplored. There is no comprehensive methodology for assessing the impact of youth migration on the economic development of regions.

This determines the relevance of this study. Considering the above mentioned facts, there is an urgent need to study youth migration in the Russian Federation and the search for mechanisms of state influence on these processes.

The problem of human capital increasing in Russia is running into a demographic crisis. This crisis is of a systemic nature and is associated with the excess of mortality over the birth rate, the aging of the nation, and the departure of a part of the population to other countries for permanent residence. That is why the demographic problem is considered in this work from the point of view of youth migration.

«Migration is the movement of the population from one settlement to another, as a rule with a change of residence, and for labor resources - the place of supply of labor» [22]. This is an extremely complex and dynamic phenomenon that takes place within the regions of the country, as well as between different states. Migration has both positive and negative consequences, so it is vital to learn how to control this process and develop tools for its regulation. Thus, there 
is a need for analysis and control of this process in order to develop effective mechanisms of influence.

This problem cannot be ignored, although, against the global problem of migration to the Eurozone, interest in internal migration processes has been partially lost.

The aim of the study is to analyze youth migration in
Today, the structure of the Crimean population by age composition is close to the national average: for example, the share of the working-age population in the country is $56 \%$, and in Crimea it is $54 \%$, the share of children in both Russia and Crimea is $18 \%$, the share of older people is 25 and $27 \%$ respectively. As for the demographic burden ratio, in Crimea at the beginning of 2020 it was amounted to 845 disabled

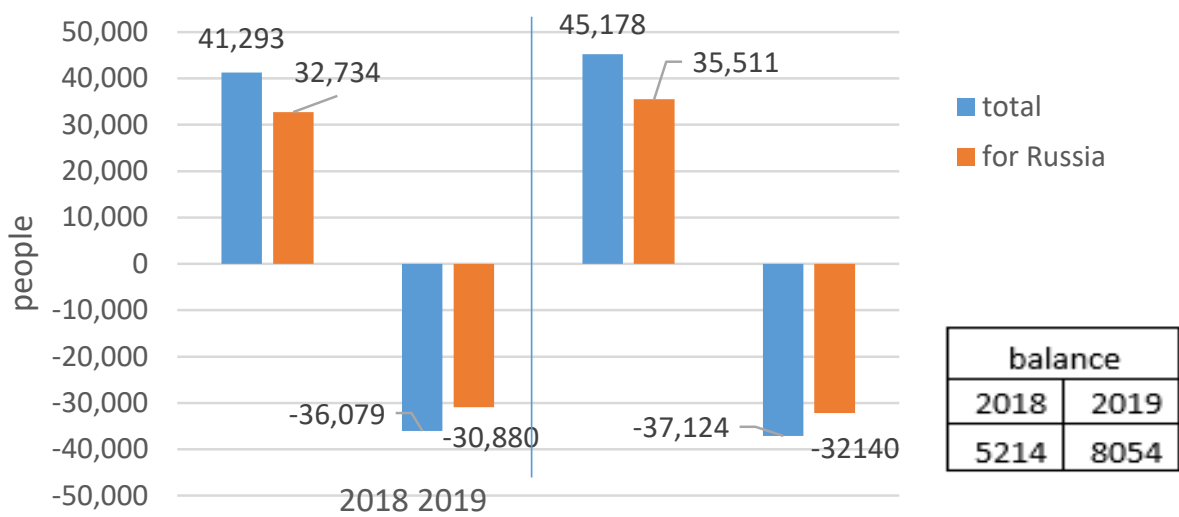

Fig. 2 Migration movement of the population in the Republic of Crimea *

* - built by the author based on [25]

Russia as a whole and in Crimea particularly and to study its impact on the economic development of regions and the state as a whole.

Russia has developed its own characteristics of migration processes, which can be briefly defined as: «brain drain» and «drainage of ideas» from the country and regions. Speaking another words, there is a process of migration of the most active and educated population, which are the basis of the Russian «human capital».

We will begin our analysis of youth migration by examining the age structure of the Russian population, since this provides a basis for predicting the labour force in the future. Rosstat has published the most likely long-term demographic forecast for Russia as a whole. Figure 1 shows a diagram constructed by the author based on this forecast. The diagram shows that, according to the forecast, in the next 15 years the population of the country will decrease from today's 146.5 million people to 143 million people, that is, by 3.5 million people in Russia. At the same time, Rosstat predicts an increase in the working-age population by 6.1 million people from 82 to 88.1 million people (from $56 \%$ to $61.7 \%$ ) over the same periodfigure. But even under such conditions, Rosstat «considers the demographic burden of 775 disabled citizens at the beginning of 2020 (a reduction to 622 disabled citizens per 1000 able-bodied citizens is forecasted by 2036)» [26]. The gradual decline in population over the next 15 years will lead to this. An extremely negative trend is especially the reduction in the number of children from today's 27.3 ( $18.7 \%$ of the population) to 20.3 million people (14.2\% of the population) in 2035. Taking into account the growing trend towards centripetal youth migration (to the capital and to large cities of the country), the problem of the outflow of the most qualified young people will escalate in the regions. This problem also affected the Crimea. citizens per 1000 people of working age, which is $9 \%$ higher than in Russia as a whole. The demographic burden in Crimea is large. In addition, there is an extremely high migration rate in Crimea.

Crimea attracts migrants by a number of factors: geographical location, developed tourism, natural and climatic conditions, comfortable living and recreation conditions, well-developed infrastructure, which development takes a lot of state's money. The federal target program «Social and economic development of the Republic of Crimea and the city of Sevastopol until 2022» with a funding of 961 billion rubles [8] ensures the development of Crimea in various directions.

New trends began to form in the region after the entry of Crimea into the Russian Federation, including those related to the migration. Data on the dynamics of the aggregate migration movement of the population in the Republic of Crimea for 2018-2019 are presented in Figure 2. Migration to and from Crimea within Russia is separately highlighted.

As can be seen in the diagram, migrants from the regions of Russia make up almost $80 \%$ of the total amount of Crimean migrants. It can also be noted that there are more arriving migrants than leaving: so in 2018 the migration balance was 5214 people, and 8054 people in 2019, meaning that people remain in Crimea. As a result, the population of Crimea is increasing. Most of the migrants come from mainland Russia. At the same time, the main flow of migrants to Crimea - about 40 thousand people - is associated with labor migration, which has a evident seasonal character (its peak falls on the summer months) and at the end of the season these people leave for home. What does attract migrants to Crimea?

Investments in the Republic of Crimea and Sevastopol increase the attractiveness of the region for people looking for work. Crimea needs specialists in various professions at 
the present stage, and people are ready to come to Crimea for the season. The workforce grows when young, full of energy people arrive. This contributes to an increase gross regional product in the host region. In addition, labor migrants who are officially employed have a positive effect on the budget of the host region. The bulk of labor migrants are young healthy people, whose arrival does not create an additional burden on the social sphere of the region. These are the positive aspects of migration.

However, there are also negative sides. For example, young people are leaving Crimea and this fact causes worsening of the demographic situation on the peninsula. In addition, the high level of migration of people of disabled age to Crimea for health reasons has the opposite effect: the structure of the population changes - the share of the workingage population decreases, the economic growth of the region per one inhabitant of the region slows down, and the burden on social infrastructure grows.

Let's analyze reasons for youth migration from Crimea. «78\% of migrants aged 18-19 stated that they emigrated in connection with their studies». Youth migration is mainly due to the relocation associated with obtaining education.

However, young people do not return to their hometown or village in most cases. They prefer to evolve in a big city and stay there on a permanent basis. «Irretrievable» migration from Crimea negatively affects the development of the region. Young people say that the reason for this choice is the insufficient quality of life in Crimea [12]. Let's examine a generalized indicator of the quality of human capital - the human development index - it is an «aggregated indicator that characterizes the quality of life in a certain area in three directions» [16]: health and longevity; access to education; standard of living.

The dynamics of the human development index for Russia and the Crimean region is presented in Table 1.

TABLE I. DYNAMICS OF THE HUMAN DEVELOPMENT INDEX IN 20152017 [26]

\begin{tabular}{|c|l|c|c|c|c|}
\hline Place & \multicolumn{1}{|c|}{ Subject } & $\begin{array}{c}\mathbf{2 0 1 5} \\
\text { year }\end{array}$ & $\begin{array}{c}\mathbf{2 0 1 6} \\
\text { year }\end{array}$ & $\begin{array}{c}\mathbf{2 0 1 7} \\
\text { year }\end{array}$ & $\begin{array}{c}\mathbf{2 0 1 7 -} \\
\mathbf{2 0 1 5}\end{array}$ \\
\hline- & $\begin{array}{l}\text { Russian } \\
\text { Federation }\end{array}$ & 0.875 & 0.881 & 0.890 & 0,045 \\
\hline 1 & Moscow & 0.949 & 0.952 & 0.960 & 0,011 \\
\hline 75 & Sevastopol & 0.793 & 0.820 & 0.832 & 0,039 \\
\hline 76 & $\begin{array}{l}\text { Republic of } \\
\text { Crimea }\end{array}$ & 0.804 & 0.817 & 0.831 & 0,027 \\
\hline
\end{tabular}

The index ranges from 0 to 1 and the larger its value, the better is life. It is believed that an index value above 0.8 indicates a high level of human development.

As can be seen from the table, the human development index for both Russia and Crimea is over 0.800 , which is considered a very high level of development. However, at the same time, even with such a high human development index level, Crimea and Sevastopol are only in 75th and 76th places among all regions of Russia.

Next, we will analyze the main economic indicators that affect the Crimea migration attractiveness; they are presented in Table 2.
TABLE II. LIST OF SUBJECTS OF THE RUSSIAN FEDERATION BY GROSS REGIONAL PRODUCTPER CAPITA IN THOUSAND RUBLES.[26]

\begin{tabular}{|l|l|l|l|l|l|l|}
\hline Place & Subject & $\begin{array}{c}2014 \\
\text { year }\end{array}$ & $\begin{array}{c}2015 \\
\text { year }\end{array}$ & $\begin{array}{c}2016 \\
\text { year }\end{array}$ & $\begin{array}{c}2017 \\
\text { year }\end{array}$ & $\begin{array}{c}2018 \\
\text { year }\end{array}$ \\
\hline- & $\begin{array}{l}\text { Russian } \\
\text { Federation }\end{array}$ & 405,1 & 449,1 & 472,2 & 510,3 & 578,7 \\
\hline 6 & Moscow & 1051,6 & 1102,5 & 1157,4 & 1263,7 & $\begin{array}{l}1423, \\
6\end{array}$ \\
\hline 77 & $\begin{array}{l}\text { Republic } \\
\text { of Crimea }\end{array}$ & 100,5 & 139,9 & 165,4 & 187,7 & 204,6 \\
\hline
\end{tabular}

Crimea significantly lags behind the other regions of the Russian Federation in gross regional product per capita, getting into the top ten outsider regions.

However, during 2014-2018 this index in Crimea has more than doubled, but it still remains 2.5 times lower than the national average. In addition, Crimea has a low level of income, as it evidenced by the data presented in Table 3.

TABLE III. INDICATORS OF THE LEVEL OF INCOME IN CRIMEA

\begin{tabular}{|c|c|c|c|}
\hline Index & $\begin{array}{c}\text { Russian } \\
\text { Federation }\end{array}$ & Sevastopol & $\begin{array}{c}\text { Republic of } \\
\text { Crimea }\end{array}$ \\
\hline Salary level in 2019 (place) & - & 47 & 62 \\
\hline $\begin{array}{ll}\text { 1)the share of highly paid } \\
\text { workersa. } & \text { (salary> } 100 \\
\text { thousand rubles per month), } \%\end{array}$ & 7 & 2,2 & 1,5 \\
\hline $\begin{array}{l}\text { 2)the share of low-paid workers } \\
\text { (salary< } 15 \text { thousand rubles per } \\
\text { month), } \%\end{array}$ & 11 & 19,2 & 19 \\
\hline $\begin{array}{l}\text { 3)median salary, thousand } \\
\text { rubles. per month }\end{array}$ & 32,9 & 26,6 & 24,8 \\
\hline $\begin{array}{llll}\begin{array}{l}\text {-personal income } \\
\text { (place) }\end{array} & \text { in } & 2019 \\
\end{array}$ & - & 35 & 76 \\
\hline $\begin{array}{l}\text {-the ratio of income to a fixed } \\
\text { set of goods and services, times }\end{array}$ & 1,65 & 1,53 & 1,22 \\
\hline $\begin{array}{l}\text {-the share of the population } \\
\text { below the poverty line, } \%\end{array}$ & 12,3 & 11,6 & 17,2 \\
\hline
\end{tabular}

AND IN THE CITY OF SEVASTOPOL [26]

A minimum list of indicators that characterizes the income of the Crimeans, to analyze was selected. The table shows that in 2019, considering income level, Crimeans were in 76th place among all constituent entities of the Russian Federation, i.e. Crimea is one of the ten regions of the country with the lowest incomes of the population. The situation is better in Sevastopol - it is 35th according to the income level. The share of the Crimean population below the poverty line exceeds $17 \%$ (this means every sixth inhabitant of the peninsula), while in the country as a whole, this index is $12.3 \%$. $19 \%$ of the Crimean population receive salaries below 15 thousand rubles, while the subsistence minimum in Crimea at the beginning of 2020 accounts for 11,243 rubles. As a result, Crimea ranked 62nd in 2019 considering level of salaries.

Of course, young people tend to go to regions that are more attractive from an economic point of view. They prefer economic conditions with higher incomes and wider opportunities for self-realization. These regions in the Russian Federation include Federal cities and the most developed centers of the Federal subjects.

In modern conditions, countries compete not only for commodities and for markets, but also for «talents», which 
are understood as highly qualified specialists in various fields. «The main reason of increasing of competition for talents is associated with a structural shift in the labor market - a significant increase in demand for highly qualified specialists» [14]. Thus, countries are forced to take measures to educate, attract and retain highly qualified labor, that is, talents - the basis of global competitiveness. Now, researches are being conducted on the way countries grow, attract, and retain talents. «The top five leaders in attracting specialists are:

\section{Switzerland,}

2. Singapore,

3. USA,

4. Norway,

5. Sweden...

The Russian Federation rank is only 53rd» [14].

The leading countries are classified as «countries with high income per capita». Until the annual average income per capita exceed 4 thousand dollars, the results of countries' efforts to develop human capital are not predictable» [18].

A similar situation is observed within Russia: «the most developed regions with a high level of income are characterized by high migration attractiveness: Moscow, the Moscow region, St. Petersburg, the Leningrad region and the Krasnodar territory» [20].

It is obvious that in the donor regions there are a shortage of labor resources and a «youth deficit» due to the outflow of young people. Further, it escalates the demographic situation in the regions: there are no young people, the birth rate falls and the population is naturally declining. This trend is extremely negative for the development of regions and the country as a whole, so there is a need in measures of regulation such migration processes in a number of Russian regions.

In addition, the problem of youth migration is imposed on the current trend of reducing the proportion of youth in the country. The imposition of these trends threatens the economy of the donor region in the present and aggravates the socio-economic problems of the region in the future.

Scientists have been researching this problem for a long time and their work is aimed at building economic and mathematical models. These models link the growth rate of real GDP per capita depending on the growth rate of the working-age population in a particular territory. Thus, in [2], «based on a sample of data for 78 countries for the period from 1965 to 1990 , the authors conclude that, other things being equal, with an increase in the growth rate of the share of the working-age population by $1 \%$, the GDP per capita will increase by $1.46 \%$ ».

A similar analysis was carried out in the work [13] in 78 regions of Russia for the period from 1997 to 2016. On its basis, it was concluded that «other things being equal, with an increase in the growth rate of the working-age population share by 1 percentage point, the growth rate of the gross regional product per capita averaged 78 regions of Russia increases by 1.8 percentage points». An analogue of the economic multiplier is observed. Further calculations by [13] showed that in the period under study «the first demographic dividend provided about $13 \%$ of the growth of real GDP per capita in the Russian Federation in 1997-2015.». The «demographic dividend» is «the potential for economic growth as a result of shifts in the age structure of the population, when the share of the working-age population (from 15 to 64 years old) exceeds the share of the disabled population» [13]. Assessments of the first demographic dividend for different regions of the world [5] showed that «in countries with transition economies, this dividend provided about $39 \%$ of economic growth in 1970-2000, in industrialized countries - 15\%, and in the countries of Eastern and South-East Asia - 14\%» [5]. Thus, studies prove that with the growth of the working-age population in the region, the gross product per capita grows at a higher rate.

There is no doubt that youth migration is one of the factors in the formation of the demographic dividend, but for donor regions it has a negative impact.

Impact of migration does not end with the decline in the growth rate of the gross regional product. Empirical studies conducted in the 20th century in the regions where migrants are sent have confirmed that migration encourages the region's backwardness. «Negative perspectives lead to the socalled «migrant syndrome» or a vicious circle» [3]: migration, then more underdeveloped, then migration, and so on.

This situation may threaten many Russian regions. It is known that the fundamental basis for creating highly qualified human capital is the education system. However, because of the influence of youth migration in most of Russia, the study of the problem «how to teach a professional» should be preceded by the solution of the problem «who can be teached». In the absence of young people, universities in the regions will be closed, which will again stimulate youth educational migration. The vicious circle will repeat itself.

The Crimean region has not yet fall into this vicious circle, but this is due to the increased interest of Russians in the newly acquired Crimean peninsula. Part of the Russian population moves to Crimea for various reasons, which are not the subject of this study. It is important that youth migration from Crimea is not yet noticeable on the background of the arrival of migrants in Crimea.

It should also be noted that the transformation of the demographic dividend into economic growth directly depends on the economy's ability to create jobs at the same rate as the working-age population growth increases. In addition, it depends on the socio-economic, institutional, cultural and educational policies in the region. The growth of the working-age population can lead to increased unemployment and social instability in the absence of thoughtful policies.

To prevent demographic problems, the leadership of our country has been taking certain measures. So in 2007 Decree of the President of the Russian Federation No1351 of 9.10.2007 approved the concept of demographic policy of the Russian Federation for the period up to 2025 [24].

In 2018 the national project «Demography» was developed. Its implementation period is 5 years (2019-2024). The total project budget is 3.1 trillion rubles.

Within the national project «Demography», 5 regional projects have been developed, including [24].:

- The Federal project «Financial support for families at the birth of children», 
- The Federal project «Promoting women's employment creating conditions for preschool education for children under three years of age»,

- The Federal project «Older generation»,

- The Federal project «Strengthening public health»,

- The Federal project «Sport is the norm of life» .

The national project covers a wide range of demographic problems, but does not relate to the problems of youth migration. Therefore, it is necessary to develop special regulation mechanisms to manage youth migration. Moreover, these mechanisms should be implemented at the state or, at least, at the regional level.

Similar measures have being taken at the regional levels, for example, the Strategy of socio-economic development of the Republic of Crimea until 2030 [10]. It has been developed in Crimea, as well as the concept of demographic development of the Republic of Crimea for the period up to 2025, approved by resolution of the Council of Ministers of the Republic of Crimea No. 305 of September 2, 2014 [9]. Among the strategic directions, there is «Demography and employment», within which the following targets are set:

1) «the share of highly qualified employees in the total number of qualified employees $-45 \%$,

2) population growth due to natural and migration growth of the population of the Republic of Crimea,

3) migration growth mainly of skilled labor,

4) increase in life expectancy to 77.3 years».;

These documents indicate that «the main strategic goal is to achieve high standards of quality of human life, its diverse development, continuous learning, realization of intellectual and creative potential, rest and recreation» [10]. However, achievement of these goals requires hard work. To attract young people to the region, it is necessary to create such socio-economic conditions that would strive young people to live in this region, create families, open businesses, and develop.

A survey of Crimean young people showed that the quality of life in Crimea does not suit them from their point of view for a number of reasons:

- low income,

- lack of cultural and entertainment centers,

- critically high real estate prices,

- adverse conditions for mortgage lending,

- insufficient number of jobs for narrow-profile specialists,

- a rather low level of development of high-tech industries

To solve the identified problems of youth migration, we suggest providing a number of benefits for young people returning to their home region after graduation:

- preferential mortgage (possibly with partial compensation for the cost of house at the expense of the region),

- guaranteed provision of employment by the specialty,

- additional regional payments for the birth of a child,
- building of housing under the Social Housing program,

- specialized industries relocation to Crimea,

- to increase the number of research laboratories and technology centers,

- to realize the program for the creation of the Russian «Silicon Valley» in Crimea [23].

\section{CONCLUSION}

The research is devoted to the problem of youth migration in Russia in general and in Crimea in particular. Employees, who can easily adjust to new achievements and innovations, i.e. the youth, become the most demanded. The place of human capital in the modern economy is studied in the article; the losses of the state from the «brain drain» are shown.

The study of the works of scientists on migration problems showed the ambiguity of the conclusions of different authors about the migration processes impact on the economic development of regions.

Russia has developed its own characteristics of migration processes, which can be briefly defined as «brain drain» and «drain of ideas» from the country and regions, or in other words - migration of the most active and educated population, which are the basis of Russia's «human capital». This situation should be viewed "as an internal threat to Russia's economic security".

The analysis of the forecast of the structure of the population of Russia by age showed a negative trend in the reduction of the population of Russia for the next 15 years, as well as a dangerous situation in the reduction of the number and proportion of children in the country's population. The problem of the outflow of the most qualified young people will be extremely aggravated in the regions, given the growing trend towards centripetal youth migration. This problem also affected the Crimea. The migration balance of Crimea is positive today, but this is due to the migration of people of working age and elderly people to Crimea.

It was also found that in terms of quality of life, Crimea is among the top ten outsiders, taking only 75th place according to human development index among Russian regions, and 76th place considering population income. Of course, young people strive to regions that are more attractive from an economic point of view, where incomes are higher and there are more opportunities for self-realization under such economic conditions.

It is extremely important, firstly, to organize a highquality registration of migrants, and secondly, to provide a mechanism for regulating the process of youth migration to solve these problems. This should lead to the prevention of possible negative consequences.

The accumulated human potential in a particular territory determines its prerequisites for the economic development, therefore any measures youth migration moderation will be for the benefit of the regional development.

\section{REFERENCES}

[1] G.S. Becker, "Investment in Human Capital: A Theoretical Analysis" Journal of Political Economy, vol.70, № 5 (Part 2), 1962, pp. 9-49.

[2] D.E. Bloom, J.G. Williamson, 1998. Demographic transitions and economic miracles in emerging Asia. The World Bank Economic Review, 12(3), pp. 419-455. 
[3] Hein De Haas, "Migration and Development: A Theoretical Perspective", International Migration Review: 44(1), pp. 227-264. March 2010

[4] J. Heckert "New perspective on youth migration: Motives and family investment patterns", Demographic research, vol. 33 (27), 2015, p.765-800.

[5] A. Mason, Demographic transition and demographic dividends in developed and developing countries. United Nations expert group meeting on social and economic implications of changing population age structures, Mexico City, 2005, pp. 81-101.

[6] D. G. Papademetriou Illusions and Reality in International Migration Migration and Development in Post World War II Greece. International Migration, XXIII(2), 1985, pp. 211-223.

[7] M. J. Taylor, M. J. Moran-Taylor and D. R. Ruiz Land, Ethnic, and Gender Change: Transnational Migration and Its Effects on Guatemalan Lives and Landscapes. Geoforum, 37(1), 2006, pp.41-61.

[8] Federal target program "Social and economic development of the Republic of Crimea and the city of Sevastopol until 2022". URL: http://pravo.gov.ru/proxy/ips/?docbody=\&nd=102357218 (accessed 12.10.2020).

[9] Concept of demographic development of the Republic of Crimea for the period up to 2025, approved by resolution of the Council of Ministers of the Republic of Crimea No. 305 of September 2, 2014. URL: https://mtrud.rk.gov.ru/ru/document/show/184 (accessed 12.10.2020).

[10] Strategy of social and economic development of the Republic of Crimea until 2030. URL: https://minek.rk.gov.ru/ru/structure/628 (accessed 23.11.2020)

[11] A.G. Allakhverdyan, A.V. Yurevich, Migration of scientific personnel: myths and reality, IIET RAS. Annual scientific conference, Moscow: "Janus-K", 1997, part 1, 1997, pp. 117-121.

[12] S.V. Arkhipova, Distance educational technologies and problems of youth migration, In the collection of the International Scientific and Practical Conference Distance educational technologies, Simferopol, 2020, pp. 15-17.

[13] O.S. Balash, "Spatial Analysis of the Convergence of Russian Regions", Izvestiya Saratov University. New episode. Series: Economics. Control. Right, 12 (4), 2012, pp. 48-54.

[14] N.V. Govorova, Talents and innovative development, Financial, economic and information support of the innovative development of the region: collection of materials of the II All-Russian scientific and practical conference, Simferopol: IT "Arial", 2019, pp.16-20.

[15] I.I. Eliseeva, E.K. Vasilyeva, M.A. Klupt, Demography and population statistics: Textbook, Moscow: Finance and statistics, 2006, 688 p.

[16] A. Esengeldina, "Development of human capital in the system of public service", Bulletin of the KSU, Karaganda, 2014. URL: https://articlekz.com/article/9080 (accessed 25.09.2020).

[17] Yu.G. Kobzistaya, "Human capital: concept and features", Fundamental research, No. 2, 2018, pp. 118-122.

18] M.M. Kuznetsov, "The demographic aspect of the formation of human capital in the Republic of Crimea", Society, politics, economics, law, Krasnodar, No. 6, 2015 pp. 30-37.

19]L.I. Ledeneva, E.F. Nekipelova, "Emigration intentions of elite scientific youth", Demoscope Weekly, No. 115, 2003. URL: http://ecsocman.hse.ru/data/621/119/1231/Led_2.prn.pdf (accessed 15.09.2020)

20]N.V. Mkrtchyan, "Migration of young people from small towns in Russia", Monitoring of public opinion: Economic and social changes. No 1, 2017, pp. 225-242.

21]S.Ya. Sushchiy, "Demographic potential and national structure of the population of Crimea: the end of the XX - middle of the XXI century", Regional economy. South of Russia, No 4, 2018, pp.139-149.

22]Russian Encyclopedic Dictionary: Ch. ed. A. M. Prokhorov, editorial board: V. I. Borodulin, A. P. Gorkin, V. M. Karev. Moscow, 2001, pp. 978-1023.

23] "They want to create an analogue of the Silicon Valley in Crimea" Kommersant. URL: https://www.kommersant.ru/doc/3460837 (accessed 08.11.2017).

24]Government of the Russian Federation: official site, Moscow. http://government.ru (accessed 12.11.2020).

25]Government of the Republic of Crimea: official site, Simferopol. URL: https://rk.gov.ru (accessed 12.11.2020).

26]Federal State Statistics Service of the Russian Federation: official site, Moscow. URL: http: // old.gks.ru (accessed 12.11.2020). 